\title{
THE SOCIAL AND POLITICAL ASPECTS OF NEW MEDIA (Menelusuri Jejak Kesadaran dan Tindakan Kolektif Massa)
}

\author{
Fiandy Mauliansyah \\ Program Studi Ilmu Komunikasi, Universitas Teuku Umar \\ Email: Fiandymauliansyah@gmail.com
}

\begin{abstract}
In the context of social movements, new media with all its advantages compared to the traditional media is not only a means of synchronous and asynchronous communication for a social movement, but also to mobilize and other political practices. Collective action on the social networking site, for example, does not aim to change the social order and power relations in society. However, when viewed from the perspective that it is possible destinations ideological behind the use of ICT in a collective action, and given that social networking sites have a specific design that allows messages been created in a certain way to attract attention of the public, collective action was the forerunner of a social movements. Then the question is what is true that ICTs contribute to the awareness and collective action that has now become a new phenomenon in the development of information technology? This qualitative research want to parse how the actual collective action in the New Media works. With a base of the existing literature can be argued that collective action can not be said to be equal to the social movements, but social movements contained in collective action itself. Almost all the cases of collective action that occurred in Indonesia politically charged and temporary. This allows the collectivity that occur will be dynamic. New media then supposed to be the stimulus and the means to create public awareness and collective action.
\end{abstract}

\section{A. PENDAHULUAN}

Perkembangan teknologi new media tidak bisa dilepaskan dari perkembangan komputer dan jaringan yang memungkinkan seseorang terkoneksi dan berselancar di dunia maya. Penemuan-penemuan baru di bidang ilmu teknologi ini rupanya tanpa sengaja dapat mengubah bagaimana orang-orang menggunakan teknologi dan bagaimana mereka berinteraksi di dunia sosial. Salah satu penemuan penting tersebut adalah ketika ditemukannya internet yang dapat menghubungkan dan menyatukan kita dengan realitas lain lewat bantuan komputer.

Elemen penting yang dihasilkan atas perkembangan internet itu menunjukkan internet sebagai sebuah jaringan komunikasi secara global yang membangkitkan komunitas-komunitas virtual di dunia maya. Flew (2005) menyinggung ini sebagai titik awal kebangkitan komunitas virtual di dunia maya. Artinya, komunitas yang awalnya terjalin di dunia sosial berpindah ke dalam dunia maya yang semuanya itu disatukan oleh jaringan internet. Tidak hanya komunitas virtual saja yang berhasil diciptakan internet, budaya virtual pun menurut Flew menjadi dasar keberlangsungan interaksi diantara mereka yang berpartisipasi dalam computer-mediated communication (CMC).

Sebelum teknologi computer digunakan secara masif seperti sekarang, relasi kita dalam dunia sosial begitu intim dan mesra. Kita dapat mendengarkan lawan bicara kita bercerita tanpa interupsi yang diakibatkan ponsel yang berdering atau sebentar-sebentar melirik media jejaring sosial seperti Facebook atau Twitter. Kita juga dapat lebih peka terhadap situasi dan keadaan disekitar kita, seperti memperhatikan ibu kita yang memasak sambil bercakap-cakap atau menemani kakek di rumah sambil mendengarkan ceritanya tentang masa lalu. Hubungan kita dengan tetangga juga tidak hanya sebatas salam-senyum- 
sapa namun membangun relasi yang bersifat kekeluargaan sebagai bagian dari suatu komunitas, misalnya dengan mengadakan kerja bakti, senam bersama, atau bahkan arisan.

Setelah penggunaan internet mewabah ke berbagai penjuru dunia, maka terciptalah banyak media jejaring sosial yang menghubungan satu orang dengan jutaan orang lainnya tanpa ada hambatan geografis. Heboh Facebook di tahun 2007 atau Twitter di tahun 2009 bukan semata-mata terjadi begitu saja. Perubahan kultur dalam masyarakat kita yang cenderung telah dimanjakan dengan teknologi internet membuat segala sesuatu serba cepat, mudah, dan instan. Meskipun pada awalnya jejaring media sosial dibangun untuk mendekatkan orang-orang yang terpisah jarak pun pada kenyataannya penggunaan media sosial telah meretas hubungan sosial dengan orang-orang yang ada di dekatnya.

Seiring berjalannya waktu, teknologi yang telah memuaskan kebutuhan interaksi antar individu kemudian merambah untuk memuaskan kebutuhan kolektif. Ada lebih dari satu individu bahkan mungkin puluhan, ratusan, dan jutaan orang berkumpul di dunia maya dan kemudian berkelompok dengan tujuan masing-masing. Fenomena yang terjadi kemudian, bagaimana media jejaring sosial yang dulunya digunakan untuk individu, kini digunakan pula sebagai alat gerakan sosial, misalnya gerakan 1.000.000 Facebook CicakBuaya yang sempat heboh dan berhasil memenangkan opini publik. New media lantas disinyalir menjadi stimulus sekaligus sarana untuk menciptakan kesadaran dan tindakan kolektif di masyarakat. Pertanyaannya kemudian apakah memang benar bahwa TIK memberikan kontribusi terhadap kesadaran dan tindakan kolektif yang kini menjadi fenomena baru dalam perkembangan teknologi informasi.

\section{B. KAJIAN TEORITIK}

\section{Kesadaran dan Tindakan Kolektif}

Sebelum kita berbicara tentang kesadaran dan tindakan kolektif, maka pertama-tama mari kita menelusuri tentang apa yang dimaksud dengan kesadaran. Dalam bahasa Perancis, kata conscience memiliki makna "kesadaran" yang dalam bahasa Inggris disebut consciousness dan "hati nurani" (Inggris: moral conscience). Kesadaran kolektif bermula dari kesadaran individu. Dalam bidang ilmu psikoanalisa, Freud (dalam Semiun, 2006) menyebut kesadaran merupakan satu-satunya tingkat kehidupan mental yang secara langsung tersedia bagi kita.

Kesadaran itu terbentuk dari pikiran-pikiran yang datang dari dua arah yang berbeda. Pertama, persepsi yang ditangkap melalui panca indra bila tidak terlalu mengancam akan memasuki kesadaran. Kedua, pikiran-pikiran yang tidak mengancam dari alam prasadar dan pikiran-pikiran yang tersamarkan dengan baik dari ketidaksadaran.

Pendapat lain mengenai kesadaran individu dan kolektif juga dibahas dalam bidang ilmu sosiologi. Georg Simmel, sosiolog asal Jerman ini juga membahas sedikit mengenai kesadaran individu/kolektif. Simmel menyebutnya kesadaran kreatif (Ritzer, 2012). Simmel melihat para individu atau kelompok individu yang sadar, yang saling berinteraksi karena bermacam motif, maksud, dan kepentingan. Kreativitas itu kemudian menjadi bentuk interaksi yang bermacam-macam dan tidak dapat disangkal memunculkan para aktor yang menciptakan struktur sosial, dan juga efek-efek yang dimiliki struktur-struktur itu pada kreativitas individu (Ritzer, 2012).

Definisi yang lebih mapan kemudian dikemukakan oleh Emile Durkheim, sosiolog yang pada awalnya mengembangkan konsep tentang kesadaran kolektif untuk memahami moralitas dalam masyarakat. Durkheim berpendapat bahwa kesadaran kolektif adalah seluruh kepercayaan dan perasaan bersama orang kebanyakan dalam sebuah masyarakat akan membentuk suatu sistem yang tetap yang punya kehidupan sendiri (Ritzer \& Goodman, 2013). 
Defenisi Durkheim ini kemudian diuraikan untuk melihat kesadaran kolektif secara utuh. Pertama, Durkheim berpendapat bahwa kesadaran kolektif terdapat dalam kehidupan sebuah masyarakat. Kedua, Durkheim memahami bahwa kesadaran kolektif sebagai sesuatu yang terlepas dari fakta sosial akan tetapi juga mampu menciptakan fakta sosial yang lain. Ketiga, kesadaran kolektif baru bisa terwujud melalui kesadaran-kesadaran individual. Dengan kata lain, kesadaran kolektif merujuk pada struktur umum pengertian, norma, dan kepercayaan bersama, bersifat terbuka dan tidak tetap.

Tindakan kolektif kemudian didefenisikan seperti yang ditulis oleh Flew melalui hasil observasi Shenton and McNeeley (Flew 2005) terhadap orang-orang yang berpartisipasi dalam diskusi grup online yaitu kesempatan untuk mereka yang dimarginalkan atau dianiaya oleh masyarakat untuk mengekspresikan pendapatnya dengan cara yang tidak mungkin dilakukan lewat media mainstream. Tindakan kolektif juga mengacu pada perilaku kolektif dalam dunia sosial dimana tindakan kolektif merujuk kepada massa sebagai sesuatu yang dipersiapkan oleh tindakan manusia sebagai unsur pertama dalam pembentukan massa.

\section{Kontribusi TIK Terhadap Kesadaran dan Tindakan Kolektif}

Internet merupakan media baru (new media) yang efektif dan efisien digunakan dalam membantu menggalang dukungan publik, paling tidak untuk kasus Prita Mulyasari melawan RS Omni Internasional, serta kasus penahanan Ketua Komisi Pemberantasan Korupsi (KPK) Bibit Samad Riyanto dan Chandra Hamzah. Dukungan publik tersebut ternyata membuahkan hasil. Prita, konsumen yang mengeluhkan layanan RS Omni Internasional pada sebuah milis, batal dituntut untuk tuduhan perdata pencemaran nama baik oleh RS Omni Internasional sedangkan para Ketua KPK Bibit dan Chandra dibebaskan dari tuduhan penyalahgunaan kekuasaan.

Simpati publik terhadap Prita, karyawati sekaligus ibu dua anak dari keluarga menengah perkotaan ini, dapat dilihat dari jumlah anggota akun grup Facebook "DUKUNGAN UNTUK IBU PRITA MULYASARI, PENULIS SURAT KELUHAN YANG DIPENJARA" (disingkat "Dukung Prita") mencapai 389.000 orang pada akhir 2009. Tak berhenti disitu, ketika Pengadilan Tinggi Banten menjatuhkan vonis denda Rp 204 juta, dukungan maya tersebut berubah menjadi aksi nyata "Koin Keadilan untuk Prita Mulyasari” (disingkat "Koin Keadilan").

Gerakan "Koin untuk Prita" yang semula dikampanyekan oleh para blogger di dunia maya dan akhirnya juga diberitakan oleh media televisi itu berhasil menghimpun dana sebesar Rp 615 juta pada akhir 2009. Tuduhan perdata oleh RS Omni Internasional terhadap Prita Mulyasari tersebut dibatalkan karena dianggap sebagai sebuah bentuk kesuksesan gerakan sosial digital (online social movements) dalam memobilisasi dukungan secara maya maupun secara riil melalui pengumpulan dana.

Pada awal November 2009, lebih dari satu juta friends pada akun grup Facebook "Gerakan 1.000.000 Facebookers Dukung Chandra Hamzah \& Bibit Samad Riyanto" (disingkat "Dukung Bibit-Chandra") hanya dalam waktu kurang lebih seminggu sejak ditahannya Bibit dan Chandra. Pada akhirnya, Bibit dan Chandra hanya ditahan selama sepuluh hari dan dibebaskan dari segala tuduhan. Beberapa pihak menilai bahwa dibebaskannya Bibit dan Chandra menunjukkan gerakan sosial digital telah sukses membentuk opini publik bahwa penahanan dan tuduhan korupsi terhadap Bibit dan Chandra merupakan bentuk kriminalisasi KPK, oleh karenanya membebaskan BibitChandra merupakan strategi yang tepat untuk mengembalikan upaya pemberantasan korupsi pada jalur yang benar.

Fenomena dukungan warga pada suatu laman jejaring sosial (social networking sites) yang membuahkan hasil pada realita sosial tentu menggembirakan para aktivis dan 
pengamat gerakan sosial. Gerakan sosial digital amat mungkin untuk terus digalakkan melengkapi gerakan sosial konvensional dalam upaya mengubah tata-struktur yang tidak adil di Indonesia. Akan tetapi, alih-alih menjadikan 2009 sebagai "tahun gerakan sosial online Indonesia"e, fenomena tersebut seharusnya justru mengingatkan publik bahwa gerakan sosial digital bukan hal baru di Indonesia, dan bukan hal yang tidak dapat diprediksi pula bahwa gerakan sosial digital menjadi kecenderungan umum di antara warga masyarakat Indonesia.

Dapat diprediksi, artinya, fenomena solidaritas sosial yang diprakarsai dalam medium jejaring sosial di Indonesia pada akhirnya mendapatkan hasil yang sejalan dengan tujuan yang ingin dicapai, meski isu mana yang kemudian menjadi wacana publik Indonesia bisa jadi muncul secara acak. Bagaimana pun, kedua gerakan tersebut lahir pada konteks Indonesia yang telah menjadi negara yang demokratis sehingga siapa pun warga Indonesia dengan bebas menjadi pengikut sebuah cause virtual yang segagasan dengannya. Apalagi, pertumbuhan pengguna Facebook di Indonesia sejak 2008 terus meningkat tajam3, terutama pada November 2009, kurun waktu yang sama dengan semakin ramainya berita sensasional "Cicak Versus Buaya"4 di media massa arus utama.

\section{Aksi Kolektif "Dukung Prita" dan "Dukung Bibit-Chandra"}

Alih-alih menjelaskan panjang lebar mengenai aksi kolektif digital, sebaiknya kita mengenal dulu gerakan sosial dan dampak Internet terhdap gerakan sosial. Dengan begitu akan terlihat apakah aksi "Dukung Prita" dan "Dukung Bibit-Chandra" tergolong dalam gerakan sosial digital.Gerakan sosial didefinisikan dengan beragam. Menurut Mario Diani (dalam Wright, 2004), gerakan sosial adalah:

“... a network of informal interactions between a plurality of individuals, groups and/or organizations, engaged in political or cultural conflict, on the basis of a shared collective identity."

Berdasarkan definisi tersebut, secara teoritis, suatu aksi kolektif disebut gerakan sosial apabila memenuhi empat elemen: jaringan individu dan atau organisasi-organisasi, berlandaskan identitas kolektif, memobilisasi orang untuk mendukung tujuan dan melakukan aksi, serta memiliki tujuan sosial dan politik (Aelst dan Walgrave, 2004). Sementara itu, sebagian definisi gerakan sosial menekankan adanya upaya untuk mengubah tatanan sosial dan politik pada suatu masyarakat di mana gerakan sosial tersebut hidup daripada sekadar memodifikasi hukum yang ada atau mengganti pemimpin politik (van de Donk, 2004; Wright 2004). Menurut Alexander (2006), gerakan sosial merujuk pada proses-proses informal maupun formal yag terdiri atas individu-individu maupun organisasi-organisasi, di mana para pimpinan maupun pengikut tersebut bersatu untuk mengubah sangsi dan ganjaran, bentuk-bentuk interaksi individu, cita-cita kebudayaan yang menyeluruh, seringkali dalam cara yang radikal.

Menurut Tilly (2004) tidak semua aksi kolektif adalah gerakan sosial. Tilly (2004) menerangkan bahwa gerakan sosial kerap dicampuradukkan dengan "aksi kolektif, organisasi dan jaringan yang mendukung suatu aksi, atau sebagai aktor unit tunggal sehingga mengesampingkan proses terus menerus perebutan dan penyusunan ulang dalam gerakan sosial maupun interaksi di antara para aktivis, dengan konstituen, target, pihak berwenang, pesaing, lawan, audiens, yang mengubah tekstur dari gerakan sosial. Salah kaprah tersebut terjadi menurutnya karena gerakan sosial muncul di mana-mana -terutama di negara yang relative demokatis- sehingga apa pun yang nampak seperti gerakan sosia disebut "gerakan sosial", padahal gerakan sosial baru dimulai sejak tiga abad yang lalu dan 
memiliki sejarah yang berbeda dengan kudeta militer, perang sipil, dan revolusi (Tilly, 2006), juga kampanye politik, perayaan patriotik, atau duka massal (Tilly, 2004).

Suatu gerakan sosial menurut Tilly (2004) adalah "interaksi-interaksi dan praktekpraktek politik tertentu yang saling terhubung, berkembang, dan memiliki kaitan sejarah satu sama lain; kombinasi unik antara kampanye, repertoar, dan pertunjukan worthiness, unity, numbers, commitment (WUNC). Menurut Tilly (2006), suatu gerakan sosial tidak muncul mendadak melainkan terbentuk sebagai reaksi atas suatu rezim pada suatu konteks sosial dan politik; suatu gerakan sosial memiliki akar sejarah yang panjang dan mampu secara ajeg bertahan pada setiap perubahan rezim -dengan mengembangkan repertoar gerakan, maupun menjadi pendorong dari perubahan rezim itu sendiri.

Selain penekanan pada unsur adanya maksud sosial dan politik dari suatu gerakan sosial, gerakan sosial memiliki ciri khas pada aspek pengelolaan yang bersifat jangka panjang dan interaktif; menyasar para pemegang kekuasaan, aktor politik, publik umum; mengklaim untuk identitas, keberpihakan, dan program yang spesifik; memanfaatkan entrepreneur politik demi durabilitas, skala, dan efektivitas gerakan; serta memanfaatkan strategi modeling, komunikasi, kolaborasi dan koalisi untuk mengadopsi gerakan pada seting yang berbeda (Tilly, 2006).

Dengan demikian, gerakan sosial merupakan sub kajian dalam aksi kolektif $($ Tilly,1978) aksi kolektif hanya dapat disebut sebagai bagian dari gerakan sosial jika aksi tersebut merupakan bagian dari sebuah repertoar - untuk melawan atau mendukung suatu rezim yang diusung jejaring aktivis maupun organisasi dan memiliki maksud pada perubahan tatanan sosial dan politik. Menurut Samuel (2004) perbedaan mendasar keduanya adalah bahwa sesuatu aksi disebut gerakan sosial karena tujuannya namun dari segi pembentukan identitas dan metode keduanya serupa. Dengan demikian aksi kolektif dapat berkembang menjadi gerakan sosial dengan meningkatkan kualitas tujuan dan skala jejaringnya.

Dari segi metode, aksi kolektif digital pun menggunakan metode-metode gerakan sosial yang telah terdampak TIK. Sebagai dampak hadirnya Teknologi Informasi dan Komunikasi (TIK), perubahan gerakan sosial tidak hanya pada variasi media komunikasi yang dimanfaatkan, melainkan pada struktur gerakan itu sendiri, yaitu tidak hanya berbentuk gerakan sosial dengan jejaring fisikal melainkan juga gerakan sosial dengan jejaring virtual dan keduanya.

Dengan demikian, gerakan sosial digital merujuk pada gerakan sosial fisikal maupun virtual yang menggunakan TIK terutama Internet untuk melakukan fungsi komunikatif seperti diseminasi dan pengunduhan informasi, rekrutmen, mobilisasi, pemaparan opini dan jajak pendapat, diskusi, memfasilitasi kontak atar pendukung, pelayanan, dan jejaring dengan pihak internal maupun eksternal gerakan, membangun koalisi, melobi, berkampanye (Edwards, 2004; van De Donk, 2004) serta untuk melakukan aksi-aksi langsung di dunia maya seperti cyberpetition, virtual protests, virtual sit-ins, virtual blockades, gripe sites, email bombs, web hacks, hingga computer viruses.

Aelst dan Welgrave (2004) membuktikan dalam penelitiannya atas 17 laman web gerakan sosial anti globalisasi. Aelst dan Welgrave menemukan bahwa situs-situs web merupakan alat yang efektif untuk memobilisasi aktual warga, dan menambah jaringan informal pertemanan sementara aksi protes ditunjukkan dalam bentuk petisi daring, hanya Protest.net yang memanfaatkan netstriking dan Friends of the Earth yang mengirimkan email-email protes kepada politisi (Aelst dan Walgrave, 2004).

Dari aspek metode dan alat aksi yang serupa, aksi kolektif digital belum tentu gerakan sosial digital dalam pengertian gerakan sosial digital yang telah dijelaskan sebelumnya.Menggunakan pengertian gerakan sosial tradisional di atas, aksi "Dukung Prita" atau "Dukung Bibit-Chandra" bisa dibilang "bukan" gerakan sosial digital. 
Permasalahannya bukan pada digital-nya, melainkan makna "gerakan sosial"-nya. Meski gerakan sosial mengenal fase laten, kedua aksi tersebut memang hanya aksi yang bersifat temporer atau tidak dapat berlangsung terus menerus sebab tujuan dari keduanya tidaklah didasari oleh seperangkat keyakinan (belief) untuk mengubah sesuatu yang akan berdampak luas bagi kepentingan masyarakat seperti perubahan sosial (Tilly, 1978), melainkan "hanya" untuk mendukung Prita dan Bibit-Chandra. Begitu ketiganya terbebas dari masalah, aksi tersebut selesai.Selain itu, kedua aksi tersebut tidak dapat diduplikasi ke teritori yang lain sebab yang menjadi tujuan dari kedua aksi tersebut terbatas pada segelintir orang di suatu negara. Jikalau ada aksi kolektif serupa di negara lain yang mendukung Prita dan Bibit-Chandra, aksi tersebut lebih merupakan aksi simpati sebab tercapai tidaknya tujuan aksi tersebut tidak memberikan nilai tambah bagi kelangsungan hidup warga setempat.

Kedua aksi tersebut juga tidak menunjukkan adanya kesadaran atas faktor sosial dan politik sebagai penyebab kasus Prita dan Bibit-Chandra dan karenanya tidak menunjukkan kepada audiens atau publik tujuan sosial politik apa yang harus mereka dukung atau tolak, misalnya untuk merevisi undang-undang nomor 18 tahun 2008 tentang Informasi dan Transaksi Elektronik (ITE); menolak liberalisasi layanan kesehatan bagi masyarakat; dan mendorong perlawanan terhadap korupsi, singkatnya, tidak ada tujuan untuk mengubah tatanan sosial politik yang dianggap tidak adil oleh kelompok pendukung tersebut. Kedua aksi tersebut tak lebih dari aksi kolektif digital, yaitu aksi berupaya mewujudkan kepentingan bersama (Tilly, 1978), baik dilakukan bersama-sama dalam suatu kelompok atau dilakukan secara soliterdemi kepentingan kelompok ( melalui media Internet, yang mana tujuan aksi untuk sesuatu yang diyakini bersama tetapi tidak selalu untuk melakukan melakukan perubahan sosial ataupun untuk mempertahankan tatanan sosial politik yang ada.

Dalam definisi ini, aksi kolektif memang konsep yang luas. Aksi kolektif dalam laman jejaring sosial tersebut memang belum bertujuan mengubah tatanan sosial dan relasi kuasa di masyarakat.Akan tetapi, bila dilihat melalui perspektif bahwa adanya kemungkinan tujuan ideologis di balik penggunaan TIK pada sebuah aksi kolektif, dan mengingat bahwa laman jejaring sosial memiliki desain tertentu yang memungkinkan pesan dikreasi dalam cara tertentu untuk menarik perhatian publik, kedua aksi kolektif tersebut merupakancikal bakal dari suatu gerakan sosial, misalnya gerakan pro kesejahteraan dan keadilan sosial. Aksi "Dukung Prita" dalam jejaring sosial barangkali adalah pengungkapan yang lebih sederhana untuk tujuan menciptakan kebebasan informasi, Internet dan berekspresi; sementara gerakan "Dukung Bibit-Chandra" dalam jejaring sosial secara implisit menunjukkan adanya gerakan perlawanan terhadap korupsi.Jika menggunakan elemen-elemen Castells (2010) tentang gerakan sosial, musuh dari gerakan pro kesejahteraan sosial itu pun jelas, yaitu pemihakan terhadap pemilik modal dan korupsi.

Identitas yang tercermin di dalam grup kedua aksi tersebut dapat dibaca sebagai warga yang peduli terhadap penciptaan kesejahteraan dan keadilan sosial, suatu identitas pada jejaring individualitas ketimbang kelompok atau gerakan sosial digital mungkin saja tidak selalu mengampanyekan secara langsung apa yang menjadi tujuan besar mereka, dan dampak luas apa yang akan dirasakan oleh semua warga, melainkan bisa berbentuk aksiaksi kolektif tersebar pada jejaring individualitas (networked individualism) untuk mendukung atau melawan sesuatu secara satu per satu,sebab TIK memudahkan individu untuk membentuk hubungan-hubungan personal yang memungkinkan orang untuk bergabung dengan lebih banyak dan lebih beragam komunitas politik daripada dalam hal dunia material (Wellman, 2000 dalam Bennet, 2004). Meski aksi solidaritas kolektif digital tersebut belum membangun kesadaran yang lebih utuh mengenai kesejahteraan dan 
keadilan sosial di benak pubik,kedua aksi tersebut memiliki metode-metode yang juga digunakan dalam gerakan sosial digital.

\section{Gerakan Sosial Digital Dan Media Massa}

Aksi kolektif "Dukung Prita" dan "Dukung Bibit-Chandra" tidak dapat untuk menjadi contoh keberhasilan suatu gerakan sosial, akan tetapi keberhasilan kedua aksi kolektif digital tersebut samahalnya dengan gerakan sosial digital pada titik tertentu memerlukan media tradisional untuk mengarustamakan gagasannya. Sebab, melalui media massa gerakan sosial tersebut mampu menyasar pada publik dan pimpinan politik sehingga semakin banyak warga yang bergabung dan terciptalah suatu opini publik maupun tekanan politik. Terutama dalam aksi kolektif digital yang memiliki target dan dampak perubahan lebih terbatas, peran media massa tidak dapat ditinggalkan untuk mendapatkan perhatian dan simpati publik yang lebih luas. Akan tetapi di sini relasi media massa, Internet dan gerakan sosial akan lebih mendalam didiskusikan.

Internet dipandang sebagai ranah publik alternatif atau tandingan yang dapat memfasilitasi interaksi komunikatif di antara warga dan memberi peluang lebih besar bagi timbulnya partisipasi politik (Dahlgren, 2004). Dalam konteks gerakan sosial, internet dengan segala kelebihannya dibandingkan dengan media tradisional tidak hanya menjadi sarana komunikasi sinkronik maupun asinkronik bagi suatu gerakan sosial, melainkan juga untuk melakukan mobilisasi dan praktek-praktek politik lainnya (Dahlgren, 2004). Internet memberikan kesempatan bagi siapa pun untuk menjadi bagian dari gerakan selama ia memiliki sumber daya, akses dan kapasitas untuk memanfaatkan Internet (Wilhelm, 2004).

Sebelum hadirnya Internet, media massa penting bagi gerakan sosial sebab gerakan sosial memerlukan media sebagai alat untuk mengungkapkan protes dan membantu mempengaruhi pembentukan opini publik dan para pembuat kebijakan (Rucht, 1994). Komunikasi dalam gerakan sosial diarahkan ke dua pihak, yaitu pihak internal gerakan seperti di antara partisipan, dan pihak eksternal gerakan seperti pengamat maupun oposan, yang mana komunikasi ini amat menentukan kualitas pengelolaan maupun tercapai tidaknya tujuan dari gerakan sosial tersebut (Wright, 2004). Beragam bentuk komunikasi dapat dilakukan oleh suatu gerakan, baik komunikasi tatap muka atau komunikasi termediasi. Bentuk komunikasi yang dipilih ini beragam, kadangkala terkait dengan target dari komunikasi tersebut. Apabila target suatu gerakan adalah mobilisasi kualitatif, interaksi tatap muka biasanya menjadi strategi suatu gerakan untuk mendapatkan dampak besar namun terbatas (Rucht, 2004).

Sementara itu, tak hanya untuk menunjukkan eksistensi suatu gerakan, bila target gerakan sosial adalah pada mobilisasi kuantitatif, media massa dibutuhkan untuk membantu memobilisasi sebanyak mungkin orang sebab semakin besar perhatian dan dukungan publik diharapkan akan mengesankan dan mempengaruhi para pembuat keputusan yang memanfaatkan media sebagai sumber informasi dan alat komunikasi (Rucht, 2004). Gerakan sosial akan "hadir" di hadapan publik dan penguasa melalui liputan media massa atas suatu repertoar aksi aksi yang diharapkan bernilai berita bagi media massa. Apakah disiarkan atau tidak, bagaimana framing media atas aksi tersebut akan nampak pada media massa, apa pun reaksi media atas aksi aksi tersebut mensinyalkan kesuksesan atau kegagalan suatu gerakan yaitu apakah mereka diterima atau ditolak oleh publik akan terlihat melalui media massa (Rucht, 2004).

Reaksi media tradisional sulit untuk dipastikan. Publisitas yang baik oleh suatu gerakan sosial digital belum tentu mendapat framing positif dari media massa tradisional (Bennet, 2004). Bahkan masih mungkin terjadi media massa tidak mengekspos pesan yang ingin disampaikan oleh gerakan sosial digital tersebut, melainkan justru menonjolkan aspek sensasional gerakan. Kehadiran media baru menjawab ketidakpastian media tradisional 
tersebut dengan menjadi ranah publik baru di mana laman web, video sharing, laman jejaring sosial, dapat yang dihasilkan tidak harus melalui proses penyuntingan oleh editor dan dapat diciptakan dengan konvensi-konvensi yang lebih sederhana (Harper, 2003). Internet dengan mudah menjadi ranah maya bagi tumbuhnya media-media yang dikelola oleh warga, komunitas, maupun organisasi sosial.Tanpa membangun sebuah laman jejaring berbayar, seorang aktivis gerakan dapat berkomunikasi melalui Weblog yang kemudian menjadi bagian dari aktivisme di blogosphere.

Gerakan sosial yang berlangsung saat ini di seluruh dunia tergolong sebagai gerakan sosial baru (new social movements), suatu gerakan yang tidak lagi secara esensial berlandaskan pada kelompok-kelompok homogen dengan ikatan relasi yang rekat, harus disatukan oleh kesamaan wilayah dan lokasi sosial, sentralisasi, formalitas dan kepemimpinan yang kokoh, melainkan gerakan sosial baru yang terdiri dari konstituen yang heterogen, relasi yang cair, dan tidak dibatasi wilayah nasional (Van de Donk, 2004).Gerakan sosial baru ini cenderung mengusung nilai-nilai keberagaman, desentralisasi, informalitas, dan demokrasi akar rumput, sehingga dapat diperkirakan gerakan sosial baru dengan nyaman mengadopsi media yang sesuai dengan kebutuhan ideologis dan organisasional (van De Donk, 2004), dalam hal ini Internet mampu memenuhinya, terbukti Internet dapat memfasilitasi tumbuhnya partisipasi politik sebab aksi politik lebih mudah, cepat, dan universal -siapa pun dapat memanfaatkannya untuk diselenggarakan (Aelst dan Walgrave, 2004).

Menurut van de Donk, meski partai politik juga mengalami perubahan akibat penggunaan Internet, manfaat yang lebih besar barangkali lebih dirasakan oleh gerakan sosial yang diinisasi oleh warga (van De Donk, 2004). Menurut Edwards (2004) dampak penggunaan Internet untuk fungsi-fungsi politik dalam gerakan sosial adalah; a) fungsi manajemen frame: Internet menjadi medium untuk memaparkan frame dan definisi masalah dan sebagai sebuah ranah untuk menciptakan pemahaman bersama serta identitas di antara anggota dan konstituen; b) fungsi mobilisasi sumber daya: kemampuan organisasi untuk membuat jejaring, membangun sumber daya, mengedarkan informasi, merekrut dan memobilisasi orang-orang; c) fungsi memelihara relasi dengan lingkungan: meningkatkan kapasitas organisasi untuk memelihara jaringan dan untuk mengkoordinasi aksi.

Aksi kolektif "Dukung Prita" dan "Dukung Bibit-Chandra" dapat berkembang menjadi suatu gerakan sosial dengan mewacanakan masalah secara lebih strategis dan menentukan tujuan bersama yang dapat berdampak perubahan sosial sekaligus yang dapat mengikat sebagai identitas kelompok. Aksi kolektif "Dukung Prita" menunjukkan adanya mobilisasi pendukung melalui pengumpulan koin ratusan juta rupiah namun keberhasilan mobilisasi dukungan itu tak lepas dari faktor media elektronik yang kerap menayangkan berita mengenai kasus Prita.Gerakan sosial membutuhkan dukungan lebih dari itu yaitu mampu membangun jejaring yang lebih luas baik individu, kelompok, dan organisasi yang sepaham.

Secara khusus di Indonesia, Internet pada masa pra-reformasi era 1990-an dimanfaatkan dalam gerakan sosiopolitik untuk reformasi paling sedikit untuk tiga hal, yaitu diskusi demokrasi dan HAM, koordinasi aksi, propaganda, dan sumber informasi alternatif. Fitur-fitur Internet yang digunakan dalam gerakan saat itu adalah email, mailing list group, dan websites. Bermula dari penggunaan Internet oleh jejaring lembaga sosial masyarakat (LSM) di Indonesia sejak 1990, sampai munculnya Tempo Interaktif dan koordinasi demonstrasi besar pada 1998, Internet secara konsisten menjadi media komunikasi andalan dalam gerakan anti-Soeharto dan menjadi sumber informasi alternatif semenjak tekanan terhadap media massa arus utama semakin ketat. Aktivitas penggunaan Internet pertama untuk gerakan sosial yang tercatat adalahLembaga Bantuan Hukum (LBH) mengunggah laporan-laporan pelanggaran hak asasi manusia (HAM) pada laman 
milis Apakabar yang dimoderatori oleh John McDougall, seorang warga Amerika Serikat (Tedjabayu, 2011). Baru pada 1995, Internet menjadi ranah maya kontestasi antara para pendukung rezim dengan kelompok anti Soeharto. Laman-laman web seperti SiaR, MateBEAN, MeunaSAH, MamberaMO, KDPNetdan AJINews muncul menjadi sumber informasi alternatif bagi warga (Tedjabayu, 2011). Dokumen-dokumen yang diunggah dalam milis-milis, maupun diskusi-diskusi.

HAM dan demokrasi itu sendiri juga kemudian diunduh untuk digandakan dan diedarkan secara luring (Tedjabayu, 2011). Meskipun Internet memiliki kelebihan daripada media massa, media massa tetap diperlukan oleh suatu gerakan sosial digital sekalipun. Sebab, selain media tradisional yang telah hadir lebih dulu masih menjadi sumber informasi utama publik maupun pembuat keputusan, munculnya suatu liputan atas sebuah aksi gerakan sosial pada dunia maya mengindikasikan tercapainya upaya pengarusutamaan gerakan, dan ini artinya kesempatan suatu gerakan mendapatkan simpati publik akan meningkat. Gerakan sosial digital kerap dikonotasikan sebagai gerakan sosial "bawah tanah", ada, hanya bagi yang memiliki minat atau kegelisahan terhadap suatu masalah yang menjadi akar tumbuhnya gerakan tersebut. Prawacana pendukung grup laman sosial digital diperlukan karena suatu laman web di Internet menarik orang-orang yang mampu secara mandiri mengakses informasi dengan disertai wawasan yang telah ada sebelumnya, atau tahu betul apa yang mereka cari sehingga atomisasi informasi dan audiens amat mungkin terjadi (Waltz, 2005; Rucht, 2004), atau "homophily", istilah yang digunakan oleh Wilhelm (2003). Misalnya, partisipan gerakan sosial kiri akan lebih banyak mengakses blog-blog yang mengkampanyekan ideologi kiri, sementara partisipan gerakan sosial kanan akan lebih sering mengunjungi blog-blog gerakan sosial kanan. Meski media baru secara teknis bersifat inklusif dan universal -dapat dimanfaatkan oleh siapa pun yang memiiki akses dan kapasitas- hirarki akses maupun popularitas suatu laman bagia suatu kelompok tetap terjadi (Waltz, 2005).

Untuk menjangkau mereka yang berada di luar kedua gerakan tersebut, atau untuk menciptakan sekelompok pengamat, atau untuk menarik perhatian penguasa, media tradisional menjadi wahana yang paling tepat bagi gerakan sosial dalam memberitakan suatu aksi gerakan sosial. Sebagaimana surat kabar yang tetap beredar dan pesawat radio yang masih terus mengudara meski televisi telah bersiaran, Internet tidak dapat mengurangi nilai media massa tradisional. Even massa seperti petisi daring, kampanye daring dan netstrike kerap diabaikan oleh target yang disasar, sehingga ekspos terhadap aksi tersebut supaya menjangkau pengamat yang lebih luas amat bergantung pada media massa (della Porta dan Diani, 2006). Selain itu, media baru bagaimana pun tetap secara erat terintegrasi dengan media tradisional seperti media cetak dan media penyiaran, diskusi-diskusi yang berlangsung dalam sejumlah blog, laman web, dan milis merujuk pada dan berupaya untuk mempengaruhi isi format media yang lain (Waltz, 2005), sehingga terjadilah "aliran informasi dari media mikro menuju media massa dan terbentuknya persilangan audiens di antara keduanya" (Bennet, 2004).

Dengan demikian, meskipun Internet menjanjikan banyak kemungkinan untuk melakukan gerakan sosial digital, suatu gerakan sosial digital tidak selalu atau tidak sepenuhnya berarti memobiliasasi dukungan secara digital, melainkan juga secara real dan tetap memperhitungkan perlukah faktor media massa dalam gerakan. Apabila suatu gerakan menekankan pula aspek pengungkapan protes, gerakan tersebut memerlukan suatu bentuk pengungkapan untuk mempengaruhi pengambil keputusan, biasanya diwakili oleh aktor-aktor yang berpengaruhdan disebarluaskan media massa (della Porta dan Diani, 2006:) yang secara tradisional menyunting peristiwa yang dianggap layak untuk disiarkan atau dicetak sehingga pengambil keputusan segera dapat menyimak apa yang sedang terjadi di luar sana. "Munculnya pemberitaan gerakan sosial digital pada media arus utama 
menunjukkan bahwa aksi protes melalui dunia maya tersebutsejalan dengan kepentingan media -tetap dengan mempertimbangkan keberpihakan media, sebab media tertarik pada suatu gerakan yang memililiki nilai emosional tinggi dan isu simbolik yang menciptakan suasana konsensus, emosi, dan kebersamaan (Walgrave dan Manssens, 2000 dalam della Porta dan Diani, 2006).

\section{KESIMPULAN}

Perkembangan teknologi informasi dan teknologi telah menghasilkan perubahanperubahan dalam tindakan kolektifitas masyarakat. Internet yang menjadi bagian dari pada perkembangan itu kini mampu menjadi jalan alternatif bagi penggalangan kepentingan publik.Internet sebagai salah satu perkembangan teknologi komunikasi itu dipandang sebagai ranah publik alternatif atau tandingan yang dapat memfasilitasi interaksi komunikatif di antara warga dan memberi peluang lebih besar bagi timbulnya partisipasi politik. Ada anggapan umum yang menyatakan bahwa implementasi dari pada teknologi informasi dan komunikasi ditentukan sejauh mana teknologi mampu membuka akses kepada berbagai pelayanan dan jaringan informasi. Semakin banyak layanan dan jaringan informasi yang tersedia, maka semakin banyak pula orang yang mengimplemetasikan teknologi itu sendiri sehingga dari itu muncul berbagai macam bentuk kesadaran dan tindakan kolektif.

Aksi kolektif dalam laman jejaring sosial misalnya, memang belum bertujuan mengubah tatanan sosial dan relasi kuasa di masyarakat.Akan tetapi, bila dilihat melalui perspektif bahwa adanya kemungkinan tujuan ideologis di balik penggunaan TIK pada sebuah aksi kolektif, dan mengingat bahwa laman jejaring sosial memiliki desain tertentu yang memungkinkan pesan dikreasi dalam cara tertentu untuk menarik perhatian publik, kedua aksi kolektif tersebut merupakancikal bakal dari suatu gerakan sosial. Tindakan kolektif tidak bisa dikatakn sama dengan gerakan sosial, tetapi gerakan sosial termuat dalam tindakan kolektif itu sendiri. Hampir semua kasus tindakan kolektif yang terjadi di Indonesia bermuatan politis dan bersifat sementara. Hal ini memungkinkan kolektivitas yang terjadi akan menjadi dinamis.

Sebelum hadirnya Internet, media massa penting bagi gerakan sosial sebab gerakan sosial memerlukan media sebagai alat untuk mengungkapkan protes dan membantu mempengaruhi pembentukan opini publik dan para pembuat kebijakan. Komunikasi dalam gerakan sosial diarahkan ke dua pihak, yaitu pihak internal gerakan seperti di antara partisipan, dan pihak eksternal gerakan seperti pengamat maupun oposan, yang mana komunikasi ini amat menentukan kualitas pengelolaan maupun tercapai tidaknya tujuan dari gerakan sosial tersebut. Beragam bentuk komunikasi dapat dilakukan oleh suatu gerakan, baik komunikasi tatap muka atau komunikasi termediasi.Bentuk komunikasi yang dipilih ini beragam, kadangkala terkait dengan target dari komunikasi tersebut. Apabila target suatu gerakan adalah mobilisasi kualitatif, interaksi tatap muka biasanya menjadi strategi suatu gerakan untuk mendapatkan dampak besar namun terbatas.

Sementara itu, tak hanya untuk menunjukkan eksistensi suatu gerakan, bila target gerakan sosial adalah pada mobilisasi kuantitatif, media massa dibutuhkan untuk membantu memobilisasi sebanyak mungkin orang sebab semakin besar perhatian dan dukungan publik diharapkan akan mengesankan dan mempengaruhi para pembuat keputusan yang memanfaatkan media sebagai sumber informasi dan alat komunikasi.

\section{DAFTAR PUSTAKA}


Bennet, W.L. 2004. "Communicating Global Activism: Strengths and Vulnerabilities of Networked Politics" dalam van de Donk, W., et.al. Cyberprotest. London: Routledge.

Castells, M. 2010. The Power of Identity: The Information Age: Economy, Society, and Culture Volume Ii. West Sussex. Blackwell Publishing.

Dahlgren, P. 2004. "Foreword" dalam van de Donk, W., et.al. Cyberprotest. London: Routledge.

Della Porta, D dan M. Diani. 2006. Social Movements: An Introduction. Victoria: Blackwell Publishing.

Edwards, A. 2004. "The Dutch Women's Movement Online: Internet And The Organizational Infrastructure Of A Social Movement" dalam van de Donk, W., et.al. Cyberprotest. London: Routledge.

Etzioni, A. 2003. "Are Virtual and Democratic Communities Feasible?" dalam H. Jenkins dan D. Thornburn. Democracy And New Media. Massachusets: Massachusets Institutute of Technology.

Fitri, N. 2011. "Democracy Discourses through the Internet Communication: Understanding the Hacktivism for the Global Changing". Online Journal of Communication and Media Technologies Volume: 1 - Issue: 2 - April - 2011, dikunjungi http://www.ojcmt.net/articles/121.pdf

Harper, C. 2003. "Journalism in a Digital Age” dalam H. Jenkins dan D. Thornburn. Democracy And New Media. Massachusets: Massachusets Institutute of Technology.

Head, T. 2010. It's Your World, So Change It: Using The Power Of The Internet To Create Social Change. Indiana: Que Publishing.

Hendricks, J.A. dan Denton Jr., R.E. (eds.). 2010. “Communicator In Chief: How Barack Obama Used New Media Technology To Win The White House". Plymouth: Lexinton Books.

Nip, J.Y.M. 2004. "The Queer Sisters and Its Electronic Bulletin Board: a Study of The Internet For Social Movement Mobilization" dalam van de Donk, W., et.al. Cyberprotest. London: Routledge.

Postmes, $\mathrm{T}$ dan S. Brunsting. "Collective action in the age of the Internet: mass communication and online mobilization, " dalam Social Science Computerreview, Vol. 20 No. 3, 2002290-301. Sage Publications. Diunduh http://www.nslg.net/class/Collective\%20Action.pdf

Ritzer, George. 2012. Teori Sosiologi dari Sosiologi Klasik sampai Perkembangan Terakhir Postmodern ed.VIII. Terjemahan dari Saut Pasaribu, Rh.Widada, Eka Adinugraha. Yogyakarta: Pustaka Pelajar.

Ritzer, George \& Douglas J. Goodman. 2013. Teori Sosiologi dari Teori Sosiologi Klasik Sampai Perkembangan Mutakhir Teori Sosial Postmodern. Terjemahan dari Nurhadi. Yogyakarta: Kreasi Wacana. 
Rucht,D. (2004). "The quadruple „A": Media strategis of protest movements since the 1960 "s", dalam van de Donk, W., et.al. Cyberprotest, London: Routledge.

Samuel, A. (2004). "Decoding Hacktivism: Purpose, Method, and Identity in a New Social Movement", Massachusets: Harvard University dinduh di http://www.itas.fzk.de/eng/esociety/ preprints/egovernance/Samuel.pdf

Shirky, C. (2011). "The Political Power of Social Media: Technology, the Public Sphere, and Political Change", dalam Foreign Affairs, diakses di http://www.foreignaffairs.com/articles/67038/clay-shirky/the-politicalpower of-socialmedia? page $=$ show

Stevenson, N. (2003). “Cultural citizenship: cosmopolitan questions”,Berkshire: Open University Press.

Tedjabayu.(2011). "Internet and the fall of Dicatatorship (Indonesia)." dalam Downing, J.D.H (ed.). Encyclopedia of social movement media, California: Sage Publications.

Tilly, C. (1978). "From mobilizations to social movement”, Michigan: Newberry Award Records.

Tilly, C. (2004. "Social movements”. 1768-2004., Boulder: Paradigm Publishers.

Tilly, C. (2006). “Regimes and Repertoires,” London: The University of Chicago Press.

Walgrave, P.V.A. (2004). "New media, new movements? The role of the internet in shaping theanti-globalization" movement."dalam van de Donk, W., et.al.Cyberprotest, London:Routledge.

Waltz,M. (2005). “Alternative and activist media”, Edinburgh: Edinburg University Press.

Wilhelm, A.G. (2000) "Democracy in the digital age: challenges to political life in cyberspace.. Routledge: London.

Wittkower, D.E. (2010). “A reply to Facebook critics”, dalam Facebook and philosophy, Illinois: Carus Publishing.

Wright, S. (2004). "Informing, communicating and ICT"s in contemporary anti-capitalist movements." dalam van de Donk, W., et.al (eds).Cyberprotest, London: Routledge. 